\title{
Pancreatitis Associated with the Helminth Serpinema microcephalus (Nematoda: Camallanidae) in Exotic Red-Eared Slider Turtles (Trachemys scripta elegans)
}

Judit Hidalgo-Vila, ${ }^{1,5}$ Albert Martínez-Silvestre, ${ }^{2}$ Alexis Ribas, ${ }^{3,4}$ Joan Carles Casanova, ${ }^{3}$ Natividad PérezSantigosa, ${ }^{1}$ and Carmen Díaz-Paniagua ${ }^{1}{ }^{1}$ Doñana Biological Station-CSIC, PO Box 1056, 41080 Seville, Spain; ${ }^{2}$ Catalonian Reptile and Amphibian Rehabilitation Centre (CRARC), 08783, Masquefa, Barcelona, Spain; ${ }^{3}$ Department of Health Microbiology and Parasitology, University of Barcelona, Avda Joan XXIII s/n, 08028 Barcelona, Spain; ${ }^{4}$ Current address: Department of Population Biology, Institute of Vertebrate Biology, Academy of Sciences of the Czech Republic, CZ-675 02 Konesin, Studenec 122, Czech Republic; ${ }^{5}$ Corresponding author (email: judit@mail.ebd.csic.es)

ABSTRACT: Pancreatitis associated with the helminth Serpinema microcephalus was found in three of 19 free-ranging red-eared slider turtles (Trachemys scripta elegans) captured between March 2003 and September 2004 in southern Spain. Microscopic changes were associated with parasite migrations and were characterized by central areas of necrosis surrounded by leukocytes and resulted in destruction of exocrine tissue. The blood profile of one of the three female turtles revealed eosinophilia and hyperglycemia, common in helminth infections and pancreatic disorders respectively. These are the first reported cases of pancreatitis caused by the nematode $\mathrm{S}$. microcephalus in the exotic and newly colonized host T. s. elegans.

Key words: Helminth, invasive exotic turtles, pancreatitis, reptiles, Serpinema microcephalus, Trachemys scripta elegans.

Pancreatic lesions caused by parasites commonly have been described in humans and in several other vertebrate species (McClure and Chandler, 1982; Popp and Schuster, 1989; Sandouk et al., 1997; Shad and Lee, 2001; Boruncinska and Frasca, 2002). However, only a few such cases have been reported for reptiles, including a red-bellied watersnake (Nerodia erythrogaster) and a pond turtle (unspecified species), both parasitized by helminths (Frye, 1991), and a radiated tortoise (Geochelone radiata) parasitized by a coccidian (Jacobson et al., 1994). Microscopic evidence of pancreatic helminthiasis can be detected from cross-sections of pancreas tissue with incorporated helminths or their eggs (Frye, 1991). Sub- stantial inflammatory response in the pancreas usually occurs when helminths are accompanied by pathogenic microorganisms or are migrating, inducing concomitant pancreatitis (Frye, 1991).

The red-eared slider turtle (Trachemys scripta elegans) is an invasive species commonly traded worldwide as pets (Telecky, 2001). Free-ranging individuals are widely distributed in freshwater ecosystems around the world (Newberry, 1984; Luiselli et al., 1997; Chen and Lue, 1998; Cady et al., 2004; Feldman, 2007; Perry et al., 2007). In southern Spain, successful reproduction of this exotic species has resulted in the establishment of populations in the wild, where these exotic turtles coexist with native aquatic turtles of two threatened species, the Mediterranean pond turtle Mauremys leprosa and the European pond turtle Emys orbicularis (Pé rez-Santigosa et al., 2006; 2008).

A study carried out during an eradication project and designed to estimate the impact of red-eared sliders on the native turtles assessed the turtles' health using hematologic, histologic, microbiologic, and parasitologic analyses (Hidalgo-Vila, 2006; Hidalgo-Vila et al., 2007; 2008; 2009). This study revealed that $-70 \%$ of the exotic turtles had hepatic, renal, enteric, pulmonary, and pancreatic lesions due to various pathogenic microorganisms (Hidalgo-Vila, 2006; Hidalgo-Vila et al., 2008). In contrast, no evidence of disease was observed 
in native turtle species despite the presence of similar potentially pathogenic microorganisms (Hidalgo-Vila, 2006; Hidalgo-Vila et al., 2008).

This study describes three cases of parasitic pancreatitis in free-ranging exotic red-eared sliders. Pancreatitis was caused by the nematode Serpinema microcephalus (Dujardin, 1845), an indirect life-cycle camallanid parasite characterized by a cephalic structure with ridges in the buccal valves (Baker, 1979). This parasite occurs only in turtles from the western Palearctic region (Ló pez-Neyra, 1947; Baker, 1979; Lluch et al., 1987; Kirin, 2001; Roca et al., 2005; Hidalgo-Vila et al., 2009). In the native habitat of red-eared sliders, the Nearctic region, these turtles are commonly parasitized by Serpinema trispinosus (Leidy, 1852) (Rosen and Marquardt, 1978; Esch et al., 1979). However, in the colonized areas in the south of Spain, this exotic turtle is parasitized by $\mathrm{S}$. microcephalus, which appears to occupy a similar niche to $\mathrm{S}$. trispinosus in its native range (HidalgoVila et al., 2009).

From March 2003 through September 2004, 19 adult female free-ranging exotic red-eared sliders were captured and removed from the established population of El Portil Pond, Huelva Province, southwestern Spain (37u149N, 7u029W). All captured individuals were necropsied after being humanely euthanized by intraperitoneal injection of sodium thiopental (Tiobarbital, Braun Medical). Liver, digestive tract, lungs, kidneys, heart, and pancreas were removed and examined macroscopically. Digestive tracts were opened and contents were washed with physiologic saline solution and examined for helminths under a magnifying glass. Liver, lungs, kidneys, heart, and pancreas were carefully dissected and examined as above. Recovered nematodes were isolated and preserved in $70 \%$ ethanol and temporally mounted in Amman lactophenol for identification. Tissue samples used for histopathology were fixed in $10 \%$

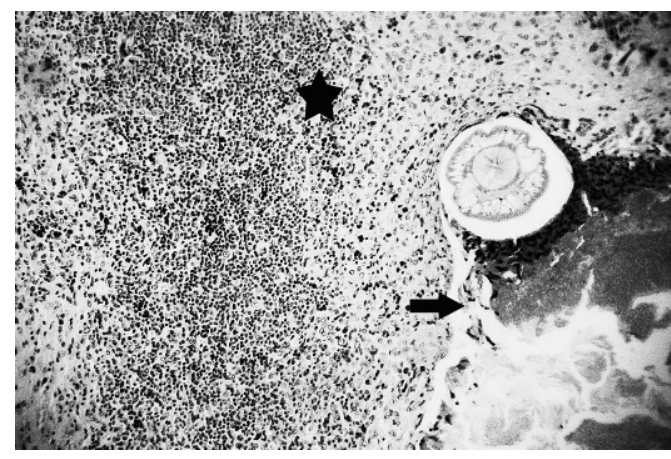

Figure 1. Section of nematode in the pancreas of a red-eared slider turtle (Trachemys scripta elegans). Note the severe granulomatous inflammatory response (arrow) due to parasite migration (star). Hematoxylin-eosin stain (4003).

buffered formalin, embedded in wax paraffin, and sectioned at $3 \mathrm{~mm}$. Sections were mounted on glass slides, stained with hematoxylin-eosin, and examined by bright-field microscopy.

Parasitologic analyses revealed nematodes in the digestive tract of the 19 turtles analyzed as well as in the pancreas of three of the 19 females. Microscopic examination of pancreatic sections revealed inflammation of the pancreas in three of the 19 individuals coinciding with the presence of nematodes in the lumen of the pancreatic ducts. According to Baker (1979), and on the basis of the identification of morphologic characteristics, some of the nematodes removed from the digestive tracts and all the nematodes found in the pancreas were identified as S. microcephalus (Hidalgo-Vila et al., 2009; Fig. 1). The main pancreatic lesions detected were granulomas-some of them visible macroscopically. Several nodules of 3-mm diameter with a hard consistency were included in the pancreatic parenchyma, deforming it and giving it a whitish appearance. Histologically, changes were observed in the pancreas, consisting of tissue destruction and inflammation, consequent to the transit of the parasite in the pancreatic tissue (Fig. 1). There was also granulomatous inflammation composed of macrophages arranged in several layers 
and fibroblasts surrounding the portions containing parasites (Fig. 1). In these areas there was also vascular neoformation with some lymphocytes around the parasites and eosinophil granulocytes. No lesions caused by parasites were detected in the remaining organs.

As is observed in higher vertebrates, pancreatitis in reptiles is often accompanied by intense inflammatory reactions and autodigestion of the pancreas, a process whereby pancreatic enzymes destroy its own tissue, leading to inflammation (Frye, 1991). In these turtles, inflammatory responses are commonly characterized by local to diffuse infiltrations of mononuclear inflammatory leukocytes and heterophils into the lobules of the pancreas (Jacobson, 2007).

Although there was a high prevalence of S. microcephalus found in red-eared sliders (93.8\%) in this locality (HidalgoVila et al., 2009), abundance and intensity of infection were not particularly strong, being similar to the values recorded in the coexisting native Mediterranean pond turtle (Hidalgo-Vila et al., 2009). Similar prevalence, abundances, and intensities of infection by $\mathrm{S}$. trispinosum were found in red-eared sliders and yellow-bellied sliders (Trachemys scripta scripta) in their native habitats of the Nearctic region (Rosen and Marquardt, 1978; Esch et al., 1979). However, no cases of pancreatitis have been reported there, even though parasites reached a much higher abundance per host (Rosen and Marquardt, 1978; Esch et al., 1979).

Additionally, hematology and blood chemistry analyses were carried out in one of the three turtles with pancreatitis in which pulmonary fibrosis, interstitial nephritis, and hepatic lipidosis were diagnosed by histopathology (Hidalgo-Vila, 2006). Hematocrit or packed cell volume was measured using a microhematocrit centrifuge technique. Red blood cell (RBC) count, white blood cell (WBC) count, and differential WBC count were determined using the methodology of
TABle 1. Hematology and blood chemistry in a red-eared slider turtle (Trachemys scripta elegans) with parasitic pancreatitis, and reference values for the species (Trachemys scripta).

\begin{tabular}{|c|c|c|}
\hline Parameter & $\begin{array}{c}\text { Affected } \\
\text { animal }\end{array}$ & $\begin{array}{c}\text { Reference } \\
\text { values }\end{array}$ \\
\hline Hematocrit (\%) & 19.79 & $12-26^{\mathrm{a}}$ \\
\hline $\operatorname{RBC}^{\mathrm{b}}\left(310^{6} / \mathrm{ml}\right)$ & 0.42 & $0.37-0.78^{\mathrm{a}}$ \\
\hline WBC $\left(310^{3} / \mathrm{ml}\right)$ & 4.95 & $9.7^{\mathrm{a}}$ \\
\hline Heterophils (\%) & 34 & $34^{\mathrm{a}}$ \\
\hline Lymphocytes (\%) & 24 & $39.50^{\mathrm{a}}$ \\
\hline Monocytes (\%) & 2 & $1^{\mathrm{a}}$ \\
\hline Eosinophils (\%) & 40 & $9.4^{\mathrm{c}}$ \\
\hline Basophils (\%) & 0 & $1.50^{\mathrm{a}}$ \\
\hline Total protein (g/dl) & 3.55 & $3.60^{c}$ \\
\hline Calcium (mmol/L) & 3.64 & $2.8^{\mathrm{c}}$ \\
\hline Phosphorus (mmol/L) & 1.68 & $1.1^{\mathrm{c}}$ \\
\hline Sodium $(\mathrm{mEq} / \mathrm{L})$ & 144.10 & $121^{\mathrm{c}}$ \\
\hline Potassium (mEq/L) & 4.36 & $4.1^{\mathrm{c}}$ \\
\hline Uric acid $(\mathrm{mmol} / \mathrm{L})$ & 0.10 & $0.059^{c}$ \\
\hline Glucose (mmol/L) & 13.66 & $3.8^{\mathrm{c}}$ \\
\hline CK (IU/L) & 995 & $1,952^{\mathrm{d}}$ AST \\
\hline$(\mathrm{IU} / \mathrm{L})$ & 201 & $53-83^{a}$ \\
\hline $\mathrm{LDH}(\mathrm{IU} / \mathrm{L})$ & 1,304 & $213-591^{\mathrm{a}}$ \\
\hline
\end{tabular}

a Stein, 1996.

${ }^{\mathrm{b}}$ RBC 5 red blood cell; WBC 5 white blood cell; CK 5 creatine kinase; AST 5 aspartate aminotransferase; LDH 5 lactate dehydrogenase.

c Dessauer, 1970.

d ISIS, 2002.

Campbell (1996). Serum chemistry values were analyzed using an automated chemical analyzer (Modular Analytics, Roche Diagnostics, Basel, Switzerland).

Analyses revealed eosinophilia, lymphoid depletion, and the presence of reactive lymphocytes with phagocytosed particles, vacuolization, and an increase of the nucleus size. Increased glucose, uric acid, calcium, aspartate aminotransferase (AST), and lactate dehydrogenase (LDH) values were also measured (Table 1).

Eosinophilia is commonly detected with helminth infections (Rosskopf, 2000) and hyperglycemia is usually associated with pancreatic disorders (Stahl, 2003). Other irregular values including leukopoenia, AST, LDH, and uric acid were interpreted as due to concomitant pathologies diagnosed. Leukopoenia is commonly associated with serious infectious diseases in reptiles (Rosskopf, 2000). High levels of 
AST and LDH are common with hepatic damage and increased blood levels of uric acid are explained by abnormal renal function (Divers, 2000). The high circulating levels of calcium would be related to the reproductive stage of this female individual (Campbell, 1996).

To our knowledge, these are the first reported cases of pancreatitis caused by $\mathrm{S}$. microcephalus in the newly colonized host, the red-eared slider. Our results provide evidence that the host-parasite relationship gives rise to damage in the exotic turtles, causing unusual cases of pancreatitis. This could be due to the poor condition of these exotic turtles. In spite of their apparent health, this free-ranging exotic population had a generalized state of immunosuppression (Hidalgo-Vila, 2006), possibly due to an inability to adapt to the newly colonized areas where they are vulnerable to pathogenic organisms and diseases. In addition to the potential impact caused by competition with native turtles for basking places, nest sites, and food (Cadi and Joly, 2003, 2004), exotic turtles of this population are a source of infection and disease, and thus pose an additional threat to the health of native fauna, for which control and regulation of the exotic pet trade are recommended.

We thank X. Ruiz, M. Florencio, A. Portheault, A. Plaza, I. Camacho-Benítez, F. Recio, A. Andreu, J. Soler- Massana, and all the volunteers for field assistance. We also acknowledge F. Jordá for English revision of the manuscript. This study was supported by Consejería Medio Ambiente, Junta de Andalucía-European Union (cofinanced project), and PAI Junta de Andalucía Research Group RNM 128. J.H. was funded by I3P-CSIC research grant. A professional American English translator carried out the English revision of the manuscript.

\section{LITERATURE CITED}

BAKER, M. R. 1979. Serpinema spp. (Nematoda: Camallanidae) from turtles of North America and Europe. Canadian Journal of Zoology 57: 934-939.

Boruncinska, J. D., AND S. Frasca, JR. 2002. Pancreatic fibrosis and ductal ectasia associated with the nematode Pancreatonema americanum sp. nov., in spiny dogfish, Squalus acanthias L., from the northwestern Atlantic. Journal of Fish Diseases 25: 367-370.

Cady, A., And P. Joly. 2003. Competition for basking places between the endangered European pond turtle (Emys orbicularis galloitalica) and the introduced red-eared slider (Trachemys scripta elegans). Canadian Journal of Zoology 81: 13921398.

, AND - 2004. Impact of the introduction of the red-eared slider (Trachemys scripta elegans) on survival rates of the European pond turtle (Emys orbicularis). Biodiversity and Conservation 13: 2511-2518.

- V. del Mas, A. C. Prévot-Julliard, P. Joly, C. Pieau, and M. Girondot. 2004. Successful reproduction of the introduced slider turtle (Trachemys scripta elegans) in the south of France. Aquatic Conservation: Marine and Freshwater Ecosystems 14: 237-246.

Campbell, T. W. 1996. Clinical pathology. In Reptile medicine and surgery, D. R. Mader (ed.). W. B. Saunders Company Ltd., Philadelphia, Pennsylvania, pp. 248-257.

Chen, T. H., And K. Y. Lue. 1998. Ecological notes of feral populations of Trachemys scripta elegans in Northern Taiwan. Chelonian Conservation and Biology 3: 87-90.

Dessauer, H. C. 1970. Blood chemistry of reptiles: Physiological and evolutionary aspects. In Biology of the reptilia, Vol. 3, C. Gans and T. Parson (eds.). Academic Press, London, UK, pp. 1-72.

Divers, S. J. 2000. Reptilian renal and reproductive disease diagnosis. In Laboratory medicine: Avian and exotic pets, A. M. Fudge and W. B. Saunders (eds.). Philadelphia, Pennsylvania, pp. 217-219.

Esch, G. W., J. W. Gibbons, and J. E. Bourque. 1979. The distribution and abundance of enteric helminths in Chrysemys s. scripta from various habitats on the Savannah River plant in South Carolina. Journal of Parasitology 65: 624-632.

Feldman, M. L. 2007. The red-eared slider turtle (Trachemys scripta elegans) in New Zealand. Turtle and Tortoise Newsletter 10: 15-18.

Frye, F. L. 1991. Common pathologic lesions and disease processes. In Biomedical and surgery aspects of captive reptile husbandry, Vol. 2, F. L. Frye (ed.). Krieger Publishing Company, Malabar, Florida, pp. 529-619.

Hidalgo-Vila, J. 2006. Hematología y perfil bioquímico sanguíneo en las especies de galápagos Mauremys leprosa y Emys orbicularis. Aspectos sanitarios y evaluació n de la introducción de la especie exótica Trachemys scripta elegans sobre 
la fauna autó ctona. PhD Thesis, University of Seville, Seville, Spain, pp. 303.

C. Díaz-Paniagua, N. Pérez-Santigosa, A. Plaza, I. Camacho, and F. Recio. 2007. Hematologic and biochemical reference intervals of free-ranging Mediterranean pond turtle (Mauremys leprosa). Journal of Wildlife Diseases 43: 798-801.

- - , C. DE Frutos-Escobar, AND

A. Herrero-Herrero. 2008. Salmonella in freeliving exotic and native turtles and in pet exotic turtles from SW Spain. Research in Veterinary Science 85: 449-452. - —, A. Ribas, M. Florencio, N. PérezSantigosa, And J. C. Casanova. 2009. Helminth communities of the exotic introduced turtle, Trachemys scripta elegans in southwestern Spain: Transmission from native turtles. Research in Veterinary Science 86: 463-465.

InTERnAtional SPECIES Information System (ISIS). 2002. Trachemys scripta common slider. Physiological reference values-American units. CDRom, Apple Valley, Minnesota.

JACOBson, E. R. 2007. Host response to infectious agents and identification of pathogens in tissue section. In Infectious diseases and pathology of reptiles. Color atlas and text, E. R. Jacobson (ed.). CRC Press, New York, New York, pp. 257298.

, J. Schumacher, S. R. Telford, and E. C. GreINER. 1994. Intranuclear coccidiosis in radiated tortoises (Geochelone radiata). Journal of Zoo and Wildlife Medicine 25: 95-102.

Kirin, D. A. 2001. New data on the helminth fauna of Emys orbicularis L. (1758) (Reptilia, Emydidae) in South Bulgaria. Comptes rendus de l'Acadé mie bulgare des Sciences 54: 95-98.

Lluch, J., V. Roca, P. Navarro, and S. Mas-Coma. 1987. Helmintofauna de los herpetos ibé ricos: Estado actual de conocimientos, consideraciones ecoló gicas y estimaciones coroló gicas. In Mamíferos y helmintos, V. Sans-Coma, S. Mas-Coma and J. Gosá lbez (eds.). Ketres Editora, Barcelona, Spain, pp. 143-161.

Lopez-Neyra, C. R. 1947. Helmintos de los vertebrados ibéricos. Vol. 3. Consejo Superior de Investigaciones Científicas (CSIC). Patronato "Santiago Ramón y Cajal" Instituto Nacional de Parasitología de Granada, Granada, Spain, 1212 pp.

Luiselli, L., M. Capula, D. Capizzi, E. Filippi, J. V. Trujillo, and C. Anibaldi. 1997. Problems for conservation of pond turtles (Emys orbicularis) in central Italy: Is the introduced red-eared turtle (Trachemys scripta) a serious threat? Chelonian Conservation and Biology 2: 417-419.

McClure, H. M., And Chandler, F. W. 1982. A survey of pancreatic lesions in nonhuman primates. Veterinary Pathology, Supplement 7: 193-209.

Newberry, R. 1984. The American red-eared terrapin in South Africa. African Wildlife 38: 186189.

Pérez-Santigosa, N., C. Díaz-Paniagua, J. HidalgoVila, A. Marco, A. C. Andreu, And A. Portheault. 2006. Características de dos poblaciones reproductoras de galápago de Florida, Trachemys scripta elegans, en el suroeste de España. Revista Española de Herpetología 20: 5-16. 2008. The reproductive ecology of exotic Trachemys scripta elegans in an invaded area of southern Europe. Aquatic Conservation: Marine and Freshwater Ecosystems 18: 1302-1310.

Perry, G., J. L. Owen, C. Petrovic, J. Lacell, and J. Egelhoff. 2007. The red-eared slider, T. S. elegans, in the British Virgin Islands. Applied Herpetology 4: 88-89.

Popp, A., AND R. Schuster. 1989. Verminous pancreatitis in Anas platyrhynchos. Angewandte Parasitologie 30: 193-194.

Roca, V., N. SÁnchez-Torres, and J. E. Martin. 2005. Intestinal helminths parasitizing Mauremys leprosa (Chelonia: Bataguridae) from Extremadura (western Spain). Revista Española de Herpetología 19: 47-55.

Rosen, R., and W. C. Marquardt. 1978. Helminth parasites of the red-eared turtle (Pseudemys scripta elegans) in Central Arkansas. Journal of Parasitology 64: 1148-1149.

Rosskopf, W. J. 2000. Disorders of reptilian leukocytes and erythrocytes. In Laboratory medicine: Avian and exotic pets, A. M. Fudge (ed.). W. B. Saunders, Philadelphia, Pennsylvania, pp. 198204.

SAndouk, F., S. Haffar, M. M. Zada, D. Y. Graham, AND B. S. ANand. 1997. Pancreatic-biliary ascariasis: Experience of 300 cases. American Journal of Gastroenterology 92: 2264-2267.

Shad, J. A., And Y. R. Lee. 2001. Pancreatitis due to Ascaris lumbricoides: Second occurrence after 2 years. Southern Medical Journal 94: 78-80.

Stahl, J. S. 2003. Diseases of the reptile pancreas. Veterinary Clinics of North America: Exotic Animal Practice 6: 191-212.

Stein, G. 1996. Hematologic and blood chemistry values in reptiles. In Reptile medicine and surgery, D. R. Mader (ed.). W. B. Saunders Company Ltd., Philadelphia, Pennsylvania, pp. 473-483.

Telecky, T. M. 2001. United States import and export of live turtles and tortoises. Turtle and Tortoise Newsletter 4: 8-13.

Submitted for publication 1 December 2009. Accepted 21 July 2010. 